\title{
PENGARUH JARAK TANAM DAN JENIS PUPUK KANDANG TERHADAP PERTUMBUHAN DAN HASIL TANAMAN JAGUNG MANIS (ZeaMays Saccharata Sturt.)
}

\section{THE EFFECT OF PLANTING DISTANCE AND TYPE OF MANURE ON GROWTH AND YIELD OF SWEET CORN (Zea Mays Saccharata Sturt)}

\author{
Putra, Rabi Dwika $^{1}{ }^{*}$, Jafrizal $^{2}$ ), Suryadi $^{2}$ ) \\ Jurusan Agroteknologi Fakultas Pertanian, Universitas Muhammadiyah Bengkulu, Jl. Bali, PO Box 118, \\ Telp. 0736-22765, fx. 26161, Website: www.umb,ac.id, Email: jafrizal@umb.ac.id, Bengkulu 38119
}

\begin{abstract}
The purpose of this study was to know the Effect of Planting Distance and Type of Manure on Growth and Yield of Sweet Corn (Zea Mays Saccharata Sthurt). The design used was factorial Randomized Block Design (RBD) with 2 factors, namely the first Planting Distance (J): $\mathrm{J} 1(50 \times 30), \mathrm{J} 2(50 \times 40)$, and $\mathrm{J} 3$ (50 X 50), while the second factor was manure (P): P1 (Chicken manure), P2 (Goat manure), and P3 (cow manure), each of treatment was repeated 3 times. The data were analyzed by using Analysis of Variance (ANOVA) and if it is significantly different, then a further test is performed with Duncan's Multiple Range Test (DMRT) of 5\%. The results showed that the effect of Spacing and Type of Manure did not significantly affect all observations of Sweet Corn (Zea Mays Saccharata Sturt).
\end{abstract}

Keywords: Sweet Corn, Planting Distance, Manure

\section{ABSTRAK}

RABI DWIKA PUTRA. Pengaruh Jarak Tanam dan Jenis Pupuk Kandang Terhadap Pertumbuhan dan Hasil Tanaman Jagung Manis (Zea Mays Saccharata Sturt).Mahasiswa Agroteknologi Fakultas Pertanian dan Peternakan Universitas Muhammadiyah Bengkulu. Di bawah bimbingan Jafrizal sebagai pembimbing utamadan Suryadi sebagai pembimbing kedua. Tujuan penelitian ini adalah untuk mengetahui Pengaruh Jarak Tanam dan Jenis Pupuk Kandang Terhadap Pertumbuhan dan Hasil Tanaman Jagung Manis (Zea Mays Saccharata Sthurt). Rancangan yang digunakan menggunakan Rancangan Acak Kelompok (RAK) faktorial dengan 2 faktor yaitu faktor pertama Jarak Tanam (J) : J1 (50 x 30), J2 (50 X 40), J3 (50 X 50), sedangkan faktor kedua Jenis Pupuk Kandang (P) : P1 (Pupuk Kandang Ayam), P2 (Pupuk Kandang Kambing), P3 (Pupuk Kandang Sapi) masing-masing perlakuan diulang sebanyak 3 kali. Hasil data dianalisis menggunakan Analisis Sidik Ragam (ANOVA) dan apabila berbeda nyata dilakukan uji lanjut Duncan's Multiple Range Test (DMRT) taraf $5 \%$. Hasil penelitian menunjukan bahwa Pengaruh Jarak Tanam dan Jenis Pupuk Kandang tidakberpengaruh nyata terhadapsemua pengamatan Tanaman Jagung Manis (Zea Mays Saccharata Sthurt).

Kata kunci : Jagung Manis, Jarak Tanam, Pupuk Kandang 


\section{BAB I.}

\section{PENDAHULUAN}

\subsection{Latar Belakang}

Jagung manis (Zea mays Saccharata Sturt.) merupakan salah satu tanaman yang disukai dan banyak dikonsumsi oleh masyarakat karena memiliki rasa yang enak dan lebih manis daripada jagung biji biasa. Jagung manis dapat dijadikan olahan makanan, bahan industri seperti bahan dasar pembuatan sirup, gula jagung, pati jagung (maizena), susu dan berbagai produk lainnya. Potensi jagung manis memiliki peluang usaha yang menjanjikan.Permintaan jagung manis semakin meningkat dengan semakin banyaknya pasar swalayan, hotel, restoran dan daerah pinggiran perkotaan yang mendukung pariwisata (Syukur dan Rifianto, 2013).

Produksi jagung manis di Indonesia pada tahun 2013 mengalami penurunan dibandingkan dengan produksi jagung manis pada tahun 2012 (Badan Pusat Statistik, 2014) Produksi jagung manis pada tahun 2013 adalah 18.506.287 ton sedangkan pada tahun 2012 adalah 19.377.030 ton. Produksi jagung di provinsi bengkulu dengan luas panen 18,257 ha dan hasil produksi 72756 ton pada tahun 2014 , kemudian mengalami penurunan pada tahun 2015 hanya mencapai 52785 ton (BPS Bengkulu, 2015). Kebutuhan jagung nasional pada tahun 2014 mencapai 19,97 juta ton pipilan kering. Produksi jagung nasional tahun 2014 sebanyak 19,03 juta ton pipilan kering, mengalami kenaikan sebanyak 0,52 juta ton (2,81 persen) dibandingkan tahun 2013 (BPS, 2015). Pertumbuhan dan produktivitas jagung sangat nyata dipengaruhi oleh jarak tanam dan varietas. Hasil jagung tertinggi di peroleh pada jarak tanam sedang yaitu $50 \mathrm{~cm}$ x 40 $\mathrm{cm}$ dengan produktivitas sebanyak $7.994 \mathrm{~kg} /$ ha di peroleh dengan hibrida P 21 (Yulisma, 2011). Pengaturan sistem tanam pada suatu lahan pertanian merupakan salah satu cara yang memiliki pengaruh terhadap hasil dari tanaman, pengaturan sistem jarak tanam berkaitan terhadap kepadatan suatu populasi di area lahan, proses penerimaan cahaya matahari yang tentunya berkaitan dengan proses fotosintesis tanaman dan persaingan hara antar tanaman. Penerapan jarak tanam yang efektif pada dasarnya bertujuan untuk memberikan kemungkinan tanaman agar tumbuh dengan baik tanpa mengalami banyak persaingan dalam hal ketersediaan air, unsur-unsur hara, dan cahaya matahari secara optimal untuk proses fotosintesis (Ikhwani dkk, 2013).

Pemupukan merupakan salah satu program intensifikasi yang dapat memperbaiki produktifitas lahan dan tanaman. Pengambilan dan pengurasan hara secara terus menerus melalui hasil panen tanpa diimbangi dengan pengembalian hara melalui pemupukan organik dan anorganik akan menjadikan tanah semakin kurus, miskin hara dan tidak produktif (Bonazir, 2005).

Pemberian pupuk merupakan salah satu faktor produksi pertanian yang sangat penting selain ketersediaan lahan, tenaga kerja dan modal, pemupukan yang berimbang memegang peranan penting dalam upaya meningkatkan hasil tanaman jagung serta rekomendasi pemupukan harus dibuat secara rasional dan berimbang berdasarkan kebutuhan hara pada tanah dan kebutuhan tanaman akan unsur hara sehingga meningkatkan efektifitas serta efisiensi penggunaan pupuk dan produksi tanpa membuat kerusakan lingkungan akibat pemupukan yang terlalu berlebihan (Tuherkih dan Sipahutar, 2008). Dari hasil penelitian yang dilakukan Alhada, (2009) Bahwa kotoran ayam sangat berpengaruh positif terhadap pertumbuhan tanaman jagung manis yaitu mempercepat pertumbuhan tanaman jagung manis. Penelitian yang dilakukan Agus Supardi (2011) 
Menurut Trisnadewi. Susila dan Wijaya, (2012). Pemberian jenis pupuk kandang terhadap pertumbuhan dan produksi jagung manis serta pengunaan dosis 20 ton/ha dapat menghasilkan pertumbuhan dan produksi jagung manis (Zea mays Saccharata Strut) terbaik.

Pada dasarnya petani indonesia kecenderungan membudidayakan tanaman jagung manis mengunakan pupuk anorganik. Pupuk anorganik tidak dianjurkan dengan dosis yang berlebihan karena akan berdampak pencemaran lingkungan. Dan apalagi jika digunakan terus-menerus akan menyebabkan produktivitas lahan menjadi menurun. Untuk memperbaiki sifat fisik dan kesuburan tanah yaitu dengan alternatif mengunakan bahan organik. Adapun upaya untuk meningkatkan produksi jagung manis yang sehat dan bebas dari bahan kimia maka perlu dikembangkan sistem pertanian yang mengacu pada penggunaan bahan-bahan organik yang ramah lingkungan dengan mengutamakan keseimbangan ekosistem (Leory, 2008).

Berdasarkan uraian di atas perlu dilakukan penelitian tentang "Pengaruh

Jarak Tanam Dan Jenis Pupuk Kandang Terhadap Pertumbuhan Dan Hasil Tanaman Jagung Manis (Zea Mays Saccharata Strut).

\section{BAB II METODE PENELITIAN}

\subsection{Tempat dan Waktu Penelitian}

Percobaan dalam penelitian ini telah dilaksanakan di Pematang Gubernur, kota Bengkulu. Mulai dari bulan Oktober 2019 sampai bulan Januari 2020.

\subsection{Alat dan Bahan}

\subsubsection{Alat}

Alat yang digunakan dalam penelitian ini adalah buku catatan, cangkul, parang, alat tulis, gembor, handspray, timbangan, meteran, mistar, tali raffia, kamera, waring (pagar).

\subsubsection{Bahan}

Bahan yang digunakan dalam penelitian ini adalah Benih jagung manis, Air, Pupuk kandang ayam,pupuk kandang kambing,pupuk kandang sapi, NPK, Insektisida, Furadan 3G.

\subsection{Metode Penelitian}

Penelitian ini dilaksanakan dengan menggunakan rancangan acak kelompok (RAK) disusun secara faktorial. Terdiri dari 2 Faktor yaitu:

Faktor pertama adalah jarak tanam ( $\mathrm{J}$ )

$\mathrm{J} 1 \quad: 50 \mathrm{~cm} \times 30 \mathrm{~cm}$

$\mathrm{J} 2: 50 \mathrm{~cm} \times 40 \mathrm{~cm}$

$\mathrm{J} 3: 50 \mathrm{~cm} \times 50 \mathrm{~cm}$

Faktor kedua adalah jenis pupuk kandang (P)

P1 : Pupuk kandang ayam

P2 : Pupuk kandang kambing

P3 : Pupuk kandang sapi 
Terdapat 9 kombinasi perlakuan: J1P1, J1P2, J1P3, J2P1, J2P2, J2P3, J3P1, J3P2, J3P3. Diulang sebanyak 3 kali ulangan sehingga terdapat 27 unit percobaan. Setiap 1 unit percobaan terdapat 16 batang tanaman jagung manis dan 4 tanaman jagung manis yang ditengah untuk diamati.

\section{$2.4 \quad$ Metode RAK}

Model linier aditif untuk rancangan acak kelompok faktorial dua factor dengan rancangan lingkungannya RAK adalah sebagai berikut :

$$
Y_{i j k}=\mu+\alpha_{i}+\beta_{j}+(\alpha \beta)_{i j}+\rho_{k}+\varepsilon_{i j k}
$$

\subsection{Analisis Data}

Tabel 3. Ragam rancangan acak kelompok factorial (RAK-faktorial) disajikan sebagai berikut :

\begin{tabular}{|c|c|c|c|c|c|}
\hline SK & DB & KT & F-hitung & F-tabel & \\
\hline Kelompok & $\mathrm{k}-1$ & JKK & KTK & & \\
\hline Perlakuan & $a b-1$ & JKP & КTP & KTP/KTG & $F(\alpha, d b-P, d b-G)$ \\
\hline A & $a-1$ & $\mathrm{JK}(\mathrm{A})$ & $\mathrm{KT}(\mathrm{A})$ & $\mathrm{KT}(\mathrm{A}) / \mathrm{KTG}$ & $\mathrm{F}(\alpha, \mathrm{db}-\mathrm{A}, \mathrm{db}-\mathrm{G})$ \\
\hline B & b-1 & $\mathrm{JK}(\mathrm{B})$ & KT(B) & $\mathrm{KT}(\mathrm{B}) / \mathrm{KTG}$ & $F(\alpha, d b-B, d b-G)$ \\
\hline $\mathrm{AB}$ & $(a-1)(b-1)$ & $\mathrm{JK}(\mathrm{AB})$ & $\mathrm{KT}(\mathrm{AB})$ & $\mathrm{KT}(\mathrm{AB}) / \mathrm{KTG}$ & $\mathrm{F}(\alpha, \mathrm{db}-\mathrm{AB}, \mathrm{db}-\mathrm{G})$ \\
\hline Galat & $\mathrm{ab}-1(\mathrm{k}-1)$ & $\mathrm{JK}(\mathrm{G})$ & KTG & & \\
\hline Total & abk-1 & JKT & & & \\
\hline
\end{tabular}

Sumber : (Syahni dan Nelly,2017)

Hasil data di analisis secara statistik menggunakan analisis ragam, selanjutnya apabila berbeda nyata dan sangat nyata maka dilanjutkan dengan uji Duncan's Multipe Range Test (DMRT) pada taraf $5 \%$.

\subsection{Pelaksanaan Penelitian}

\subsubsection{Persiapan Lahan}

\section{a. Area Lahan}

Areal lahan dibersihkan dari sisa-sisa tumbuhan atau sampah-sampah seperti kayu, batu, dan tanggul. Kemudian lahan diukur menggunakan meteran.

\section{b. Pengolahan Tanah}

Pengolahan tanah sebagai media tanam dilakukan dengan cara mencangkul area percobaan yang telah diukur secara merata, lalu dibiarkan satu minggu agar tanah yang diolah semakin gembur. Setelah dibiarkan maka diadakan pengolahan tanah kedua, dengan membagi lahan percobaan menjadi tiga bagian sesuai dengan ulangan, kemudian membuat plot percobaan berdasarkan jarak yang sudah dditentukan serta tinggi $0,3 \mathrm{~m}$. Antara plot percobaan yang satu dengan yang lain dibuat jarak selebar $0,5 \mathrm{~m}$.

\subsubsection{Persiapan Pupuk}


Pupuk kandang di dapat dari beberapa peternak dikota Bengkulu,kemudian dijemur dan timbang untuk mendapatkan berat yang konstan.

\subsubsection{Persiapan Benih}

Benih yang digunakan dalam penelitian ini adalah benih jagung manis Sweet Corn yang didapatkan dari toko pertanian yang berada di kota Bengkulu.

\subsubsection{Penanaman Benih}

Benih di tanam dalam lubang yang dibuat menggunakan tugal dengan kedalaman antara 1,5-2 cm, setiap lubang tanam diisi sebanyak 2 biji, pada setiap plot percobaan dengan jarak tanam $50 \mathrm{~cm}$ x $30 \mathrm{~cm} .50 \mathrm{~cm}$ x $40 \mathrm{~cm} .50 \mathrm{~cm}$ x $50 \mathrm{~cm}$.

\subsubsection{Pemeliharaan Tanaman a. Penyiraman}

Penyiraman dilakukan secara rutin yaitu dipagi hari atau disore hari apabila tidak terjadinya hujan. dengan cara menyiramkan keseluruh tanaman dengan jumlah air yang sama rata. karena tanaman jagung membutuhkan air pada pertumbuhannya.

\section{c. Penjarangan}

Penjarangan dilakukan pada tanaman pada saat tanaman berumur satu minggu, tanaman yang di pilih adalah tanaman yang bagus, penjarangan ini dilakukan dengan membersihkan tanaman yang tidak perlu sehingga hanya satu tanaman yang paling baik pertumbuhannya.

\section{d. Perlindungan Tanaman dari Hama dan Penyakit}

Perlindungan dari hama pada tanaman jagung manis menggunakan insektisida (Furadan 3G dan Dhitane).

\section{e. Perlindungan Tanaman dari Gulma}

Untuk menghindari persaingan antara gulma dan tanaman, maka dilakukan penyiangan. Penyiangan dilakukan setiap minggu saat terlihat gulma yang tumbuh di sekitar tanaman jagung manis dengan cara dicabut menggunakan tangan atau parang.

\subsubsection{Pengaplikasian Pupuk}

1. Pemupukan dilakukan saat olah tanah yaitu 2 minggu sebelum tanam dengan dosis 20 ton/ha dan ditambahkan pupuk dasar NPK pada saat tanaman 1 minggu setelah tanam dengan dosis $150 \mathrm{~kg} / \mathrm{ha}$ atau $48 \mathrm{gr} / \mathrm{plot}$.

2. Perlakuan dengan jarak tanam $50 \mathrm{~cm}$

x $30 \mathrm{~cm}$. Dengan pupuk kandang ayam, pupuk kandang kambing, pupuk kandang sapi. Dengan dosis pupuk 20 ton / ha.

3. Perlakuan dengan jarak tanam $50 \mathrm{~cm}$

x $40 \mathrm{~cm}$. dengan pupuk kandang ayam, pupuk kandang kambing, pupuk kandang sapi. Dengan dosis pupuk 20 ton / ha

4. Perlakuan dengan jarak tanam $50 \mathrm{~cm}$

x $50 \mathrm{~cm}$. dengan pupuk kandang ayam, pupuk kandang kambing, pupuk kandang sapi. Dengan dosis pupuk 20 ton / ha

\subsubsection{Panen Jagung Manis}

Panen dilakukan pada saat tanaman berumur 75-80 hari setelah tanam. Ciri - cirinya dapat dilihat terjadinya perubahan warna dan bentuk dari tekstur jagung manis tersebut. Dilihat 
dari daun sudah mulai berwarna kuning, kelobot berwarna hijau kekuningan, rambut tongkol berwarna kecoklatan, dan tongkol sudah terisi dengan penuh.

\subsection{Pengamatan}

\subsubsection{Diameter Batang (cm)}

Pengukuran diameter batang tanaman diukur mengunakan jangka sorong. Pengukuran dilakukan 2 minggu sekali setelah tanaman berumur 2 minggu setelah tanam.

\subsubsection{Tinggi Tanaman $(\mathrm{cm})$}

Pengukuran tinggi tanaman dilakukan dengan cara mengukur tinggi tanaman dari pangkal batang (permukaan tanah) hingga ujung daun terpanjang. Pengukuran dilakukan 2 minggu sekali setelah tanaman berumur 2 minggu setelah tanam.

\subsubsection{Jumlah Daun (helai)}

Jumlah daun dihitung dari daun yang telah terbuka sempurna pada setiap tanaman jagung manis tersebut, di lakukan 2 minggu sekali setelah tanaman berumur 2 minggu setelah tanam.

\subsubsection{Panjang Tongkol (cm)}

Pengukuran panjang tongkol dilakukan saat setelah panen, diukur menggunakan mistar.

\subsubsection{Diameter Tongkol (cm)}

Pengukuran diameter tongkol dilakukan setelah tongkol dipanen dengan menggunakan jangka sorong.

\subsubsection{Berat Tongkol Berkelobot (gr)}

Penimbangan dilakukan pada tongkol yang sudah dipanen menggunakan timbangan digital.

\subsubsection{Berat Tongkol Tanpa kelobot (gr)}

Penimbangan dilakukan pada tongkol yang sudah dibuka klobotnya, menggunakan timbangan digital.

\section{BAB III \\ HASIL DAN PEMBAHASAN}

\subsection{HASIL}

Hasil analisis keragaman untuk masing-masing faktor dam interaksinya terhadap semua parameter yang diamati yaitu dapat dilihat pada tabel 3 .

Tabel 3. Hasil analisis keragaman pengaruh jarak tanam dan jenis pupuk kandang terhadap tinggi tanaman, jumlah daun, diameter batang, panjang tongkol, diameter tongkol, berat tongkol berkelobot, dan berat tongkol tanpa kelobot.

Parameter Yang Diamati

F-Hitung

$\begin{array}{llll}\mathrm{J} & \mathrm{P} & \mathrm{JP} & \mathrm{KK}(\%)\end{array}$




\begin{tabular}{lllll} 
Tinggi Tanaman 14 Hst & $1,02 \mathrm{~ns}$ & $1,15 \mathrm{~ns}$ & $0,30 \mathrm{~ns}$ & 22.09 \\
Tinggi Tanaman 28 Hst & $0,01 \mathrm{~ns}$ & $0,12 \mathrm{~ns}$ & $0,67 \mathrm{~ns}$ & 20.94 \\
Tinggi Tanaman 42 Hst & $0,15 \mathrm{~ns}$ & $0,09 \mathrm{~ns}$ & $1,37 \mathrm{~ns}$ & 21.53 \\
Jumlah Daun 14 Hst & $0,4 \mathrm{~ns}$ & $2,45 \mathrm{~ns}$ & $2,17 \mathrm{~ns}$ & 10.19 \\
Jumlah Daun 28 Hst & $0,10 \mathrm{~ns}$ & $0,04 \mathrm{~ns}$ & $1,65 \mathrm{~ns}$ & 7.95 \\
Jumlah Daun 42 Hst & $0,02 \mathrm{~ns}$ & $0,40 \mathrm{~ns}$ & $0,27 \mathrm{~ns}$ & 12.75 \\
Diameter Batang 14 Hst & $0,59 \mathrm{~ns}$ & $0,05 \mathrm{~ns}$ & $0,38 \mathrm{~ns}$ & 13.33 \\
Diameter Batang 28 Hst & $0,51 \mathrm{~ns}$ & $0,64 \mathrm{~ns}$ & $0,19 \mathrm{~ns}$ & 24.48 \\
Diameter Batang 42 Hst & $0,71 \mathrm{~ns}$ & $0,45 \mathrm{~ns}$ & $1,40 \mathrm{~ns}$ & 15.11 \\
Panjang Tongkol & $0,38 \mathrm{~ns}$ & $0,29 \mathrm{~ns}$ & $0,02 \mathrm{~ns}$ & 11.55 \\
Diameter Tongkol & $0,64 \mathrm{~ns}$ & $3,14 \mathrm{~ns}$ & $1,54 \mathrm{~ns}$ & 15.21 \\
Berat Tongkol Berkelobot & $0,05 \mathrm{~ns}$ & $1,75 \mathrm{~ns}$ & $0,24 \mathrm{~ns}$ & 26.96 \\
Berat Tongkol Tanpa Kelobot & $0,09 \mathrm{~ns}$ & $1,99 \mathrm{~ns}$ & $0,26 \mathrm{~ns}$ & 1.37 \\
\hline
\end{tabular}

\subsubsection{Tinggi Tanaman}

Hasil analisis keragaman menunjukkan bahwa perlakuaan jarak tanaman dan pupuk kandang tidak berpengaruh nyata terhadap tinggi tanaman, Bahwa perlakuan jarak tanam dengan jenis pupuk kandang tidak menunjukkan pengaruh yang nyata terhadap tinggi tanaman 42 HST. Perlakuan jarak $50 \mathrm{~cm}$ x $40 \mathrm{~cm}$ dan Pupuk Kandang Kambing memberikan hasil yang tertinggi. dapat dilihat pada tabel 4 .

Tabel 4. Hasil pengamatan rata-rata Tinggi Tanaman pada umur 42 HST

\begin{tabular}{ccccc}
\hline \multirow{2}{*}{ Jarak Tanam } & \multicolumn{2}{c}{ Jenis Pupuk Kandang } & & \multirow{2}{*}{ Jarak Tanam } \\
\cline { 2 - 3 } & Ayam & Kambing & Sapi & \\
\cline { 2 - 3 } Jarak $50 \mathrm{~cm}$ x $30 \mathrm{~cm}$ & 113,16 & 116,08 & 126,83 & 118,69 \\
Jarak $50 \mathrm{~cm}$ x $40 \mathrm{~cm}$ & 140,25 & 119,83 & 109,33 & 123,14 \\
Jarak 50 cm x 50 cm & 95,83 & 127,25 & 126,58 & 116,55 \\
\hline Jenis Pupuk Kandang & 349,24 & 363,16 & 362,74 & 358,38 \\
\hline
\end{tabular}

\subsubsection{Jumlah Daun}

Hasil analisis keragaman menunjukan bahwa perlakuan jarak tanam dan pupuk kandang berpengaruh nyata terhadap jumlah daun. Dapat dilihat pada tabel 5.

Tabel 5. Hasil pengamatan rata-rata Jumlah Daun Tanaman pada umur 14 HST Jarak Tanam Jenis Pupuk Kandang Jarak Tanam 


\begin{tabular}{ccccc}
\cline { 2 - 3 } & Ayam & Kambing & Sapi & \\
\hline Jarak $50 \mathrm{~cm}$ x $30 \mathrm{~cm}$ & 4,83 & 3,25 & 4,25 & 4,11 \\
Jarak $50 \mathrm{~cm}$ x $40 \mathrm{~cm}$ & 4,50 & 3,58 & 4,16 & 4,08 \\
Jarak 50 cm x 50 cm & 3,75 & 4,83 & 4,75 & 4,44 \\
\hline Jenis Pupuk Kandang & 4,36 & 3,89 & 4,39 & \\
\hline
\end{tabular}

\subsubsection{Diameter Batang}

Hasil analisis keragaman menunjukkan bahwa perlakuan jarak tanaman dan jenis pupuk kandang menunjukkan tidak berpengaruh nyata terhadap diameter batang.. Dapat dilihat pada table 6 .

Tabel 6. Hasil pengamatan rata-rata Diameter Batang Tanaman pada umur 42 HST

\begin{tabular}{ccccc}
\hline \multirow{2}{*}{ Jarak Tanam } & \multicolumn{3}{c}{ Jenis Pupuk Kandang } & \multirow{2}{*}{ Jarak Tanam } \\
\cline { 2 - 4 } & Ayam & Kambing & Sapi & \\
\hline Jarak $50 \mathrm{~cm}$ x $30 \mathrm{~cm}$ & 3,27 & 3,70 & 3,37 & 3,45 \\
Jarak $50 \mathrm{~cm}$ x $40 \mathrm{~cm}$ & 3,64 & 3,39 & 3,10 & 3,38 \\
Jarak $50 \mathrm{~cm}$ x $50 \mathrm{~cm}$ & 3,20 & 3,74 & 4,06 & 3,67 \\
\hline Jenis Pupuk Kandang & 10,11 & 10,83 & 10,53 & 10,49 \\
\hline
\end{tabular}

Bahwa perlakuan jarak tanam dan jenis pupuk kandang tidak menunjukkan pengaruh yang nyata terhadap diameter batang $42 \mathrm{HST}$. Perlakuan jarak $50 \mathrm{~cm} \times 50 \mathrm{~cm}$ dan pupuk kandang kambing memberikan hasil tertinggi

\subsubsection{Panjang Tongkol}

Hasil analisiskeragaman menunjukkan bahwa perlakuan jarak tanam dan jenis pupuk kandang serta interaksi antara kedua perlakuan menunjukkan tidak berpengaruh nyata terhadap panjang tongkol. dapat dilihat pada tabel 7.

Tabel 7. Hasil pengamatan rata-rata Panjang Tongkol pada umur 77 HST

\begin{tabular}{ccccc}
\multirow{2}{*}{ Jarak Tanam } & \multicolumn{3}{c}{ Jenis Pupuk Kandang } & \multirow{2}{*}{ Jarak Tanam } \\
\cline { 2 - 3 } & Ayam & Kambing & Sapi & \\
\hline Jarak $50 \mathrm{~cm}$ x $30 \mathrm{~cm}$ & 25,33 & 24,66 & 24,19 & 24,73 \\
Jarak $50 \mathrm{~cm}$ x $40 \mathrm{~cm}$ & 26,83 & 25,66 & 26,00 & 26,16 \\
Jarak 50 cm x 50 cm & 26,16 & 25,08 & 24,83 & 25,36 \\
\hline Jenis Pupuk Kandang & 78,32 & 75,40 & 75,02 & 76,25 \\
\hline
\end{tabular}

Bahwa perlakuan jarak tanam dan jenis pupuk kandang tidak menunjukkan pengaruh yang nyata terhadap panjang tongkol 77 HST. Perlakuan jarak $50 \mathrm{~cm} \times 40 \mathrm{~cm}$ dan pupuk kandang ayam memberikan hasil tertinggi 


\subsubsection{Diameter Tongkol}

Hasil analisis keragaman menunjukkan bahwa perlakuan jarak tanam dan jenis pupuk kandang serta interaksi antara kedua perlakuan menunjukkan tidak berpengaruh nyata terhadap diameter tongkol. dapat dilihat pada tabel 8 .

Tabel 8. Hasil pengamatan rata-rata Diameter Tongkol pada umur 77 HST

\begin{tabular}{ccccc}
\multirow{2}{*}{ Jarak Tanam } & \multicolumn{3}{c}{ Jenis Pupuk Kandang } & \multirow{2}{*}{ Jarak Tanam } \\
\cline { 2 - 3 } & Ayam & Kambing & Sapi & \\
\hline Jarak $50 \mathrm{~cm}$ x $30 \mathrm{~cm}$ & 45,00 & 47,16 & 44,41 & 45,52 \\
Jarak $50 \mathrm{~cm}$ x $40 \mathrm{~cm}$ & 48,03 & 47,36 & 41,13 & 45,51 \\
Jarak $50 \mathrm{~cm}$ x 50 cm & 44,70 & 45,79 & 45,12 & 45,20 \\
\hline Jenis Pupuk Kandang & 137,73 & 140,31 & 130,66 & 136,23 \\
\hline
\end{tabular}

Bahwa perlakuan jarak tanam dan jenis pupuk kandang tidak menunjukkan pengaruh yang nyata terhadap diameter tongkol 77 HST. Perlakuan jarak $50 \mathrm{~cm}$ x $30 \mathrm{~cm}$ dan pupuk kandang kambing memberikan hasil terbaik.

\subsubsection{Berat Tongkol Berkelobot}

Hasil analisis keragaman menunjukkan bahwa perlakuan jarak tanam dan jenis pupuk kandang serta interaksi antara kedua perlakuan menunjukan tidak berpengaruh nyata terhadap berat tongkol berkelobot. dapat dilihat pada tabel 9 .

Tabel 9. Hasil pengamatan rata-rata Berat Tongkol Berkelobot pada umur 77 HST

\begin{tabular}{|c|c|c|c|c|}
\hline \multirow{2}{*}{ Jarak Tanam } & \multicolumn{3}{|c|}{ Jenis Pupuk Kandang } & \multirow{2}{*}{ Jarak Tanam } \\
\hline & Ayam & Kambing & Sapi & \\
\hline Jarak $50 \mathrm{~cm}$ x $30 \mathrm{~cm}$ & 220,25 & 223,16 & 166,97 & 203,46 \\
\hline Jarak $50 \mathrm{~cm} \mathrm{x} 40 \mathrm{~cm}$ & 220,25 & 207,50 & 184,91 & 204,22 \\
\hline Jarak $50 \mathrm{~cm} \times 50 \mathrm{~cm}$ & 220,25 & 191,50 & 194,33 & 202,03 \\
\hline Jenis Pupuk Kandang & 660,75 & 622,16 & 546,21 & 609,71 \\
\hline
\end{tabular}

Bahwa perlakuan jarak tanam dan jenis pupuk kandang tidak menunjukkan pengaruh yang nyata terhadap berat tongkol berkelobot umur 77 HST. Perlakuan $50 \mathrm{~cm} \times 30 \mathrm{~cm}$ dan pupuk kandang ayam memberikan hasil tertinggi.

\subsubsection{Berat Tongkol Tanpa Kelobot}

Hasil analisis keragaman menunjukan bahwa perlakuan jarak tanam dan jenis pupuk kandang serta interaksi antara kedua perlakuan menunjukkan tidak berpengaruh nyata terhadap berat tongkol tanpa kelobot. dapat dilihat pada tabel 10. 
Tabel 10. Hasil pengamatan rata-rata Berat Tongkol Tanpa Kelobot pada umur 77 HST

\begin{tabular}{ccccc}
\multirow{2}{*}{ Jarak Tanam } & \multicolumn{3}{c}{ Jenis Pupuk Kandang } & \multirow{2}{*}{ Jarak Tanam } \\
\cline { 2 - 3 } & Ayam & Kambing & Sapi & \\
\hline Jarak 50 cm x 30 cm & 166,00 & 162,16 & 119,66 & 149,27 \\
Jarak 50 cm x 40 cm & 195,33 & 142,25 & 131,83 & 156,47 \\
Jarak 50 cm x 50 cm & 171,08 & 130,58 & 135,66 & 145,77 \\
\hline Jenis Pupuk Kandang & 532,41 & 434,99 & 387,15 & 451,52 \\
\hline
\end{tabular}

Bahwa perlakuan jarak tanam dan jenis pupuk kandang tidak menunjukkan pengaruh yang nyata terhadap berat tongkol tanpa kelobot 77 HST. Perlakuan $50 \mathrm{~cm} \mathrm{x} 40 \mathrm{~cm}$ dan pupuk kandang ayam memberikan hasil tertinggi.

\subsection{Pembahasan}

Dari data hasil analisis ragam menunjukkan bahwa perlakuan jarak tanam dan jenis pupuk kandang tidak berpengaruh

nyata terhadap semua pengamatan (tinggi tanaman, jumlah daun, diameter batang, panjang tongkol, diameter tongkol, berat tongkol berkelobot, berat tanpa kelobot).

Jarak tanam dan jenis pupuk

kandang tidak berpengaruh nyata dikarenakan kandungan unsur hara $\mathrm{N}$ dan $\mathrm{P}$ pupuk kandang ayam $\mathrm{N}(1,75), \mathrm{P}(1,82)$ pupuk kandang kambing $\mathrm{N}(2,43), \mathrm{P}(0,73)$, pupuk kandang sapi $\mathrm{N}(2,04)$ $\mathrm{P}(0,76)$, memiliki peran yang tidak jauh berbeda

karena unsur N,P bermanfaat untuk merangsang pertumbuhan vegetatif batang (tinggi dan ukuran) dan pembentukan biji pada tanaman jagung manis sehingga tanaman dapat berkembang secara optimal dan memberikan hasil yang maksimal (Hartatik dan Widowati, 2005).

Tidak adanya pengaruh yang nyata terhadap semua pengamatan disebabkan oleh iklim yang ekstrem dimana pada saat penelitian berlangsung intensitas curah hujan sangat rendah sehingga membuat pertumbuhan tanaman jagung menjadi terganggu. Dimana curah hujan pada bulan Oktober hanya $40 \mathrm{~mm}$, November $113 \mathrm{~mm}$, dan terjadi peningkatan pada bulan Desember yaitu 242 mm. BMKG Provinsi Bengkulu (2019)

Sedangkan menurut Riwandi, (2014), bahwa curah hujan yang dibutuhkan oleh tanaman jagung sekitar $200 \mathrm{~mm}-300 \mathrm{~mm}$ perbulan atau yang memiliki curah hujan antara $800-1200$ mm pertahun.

\subsection{Kesimpulan}

\section{BAB V KESIMPULAN}

Berdasarkan hasil analisis data dan pembahasan tentang pengaruh jarak tanam dan jenis pupuk kandang terhadap pertumbuhan dan hasil tanaman jagung manis (Zea mays Saccharata Sturt), dapat disimpulkan bahwa:

1. Jarak tanam tidak berpengaruh nyata terhadap pertumbuhan dan hasil tanaman jagung manis.

2. Pemberianpupukkandangtidak berpengaruh nyata terhadap pertumbuhan dan hasil tanaman jagung manis.

3. Tidak terdapat interaksi antara jarak tanam dan jenis pupuk kandang terhadap tanaman jagung manis. 


\section{DAFTAR PUSTAKA}

Anonim. 2011. http:// thlbanyumas.blogspot.com/2011/08/ kandungan pupuk pada kotoran hewan.html. diakses tgl 6 maret 2019.

Alhada,2009. Pengaruh Kotoran Ayam Terhadap Pertumbuhan Tanaman Jagung. Artikel Penelitian.http://allhada-fisip11.web.unair.ac.id/diakses maret 2019

Bara, A. Dan M.A Chozin. 2009. Pengaruh Dosis Pupuk Kandang dan Frekuensi

Pemberian Pupuk Urea Terhadap Pertumbuhan dan Produksi Jagung (Zea mays L.) di Lahan Kering. Dalam Kumpulan Makalah Seminar Hasil Penelitian Departemen Agronomi dan Hortikultura Fakultas Pertanian Institut Pertanian Bogor.

BPS. Badan Pusat Statistik. 2015. Produksi Tanaman Pangan. Berita Resmi Statistik Provinsi Bengkulu No. 39/07/X, 1 Juli 2016.

Hartatik, W. dan Widowati, L.R. 2006. Pupuk Organik dan Pupuk Hayati. Balai Besar Penelitian dan Pengembangan Sumberdaya Lahan Pertanian. Bogor. Hlm 59-82.

Hartatik dan Widowati, 2005. Pengaruh Bentuk Dan Dosis Pupuk Kotoran Kambing Terhadap Pertumbuhan Dan Hasil Tanaman Jagung (Zea Mays L.) Lokal Madura. Diajukan untuk Memenuhi Sebagian Persyaratan dalam Memperoleh Gelar Sarjana Pertanian Program Studi : Agroteknologi. 3 Halaman.

Hasibuan,2004. Pupuk dan Pemupukan Fakultas Pertanian USU, Medan.

Ikhwani, G.R. Pratiwi, E. Paturrohman dan A.K. Makarim. 2013. Peningkatan Produktivitas Padi Melalui Penerapan Jarak Tanam Jajar Legowo. Puslitbang Tan. Pangan. Bogor.

Napitupulu Marisi, Bastianus, Z, Astuti Puji. 2014. Reaspon tanaman kacang panjang (Vigna sinesis L) terhadap pupuk NPK pelangi dan pupuk organik cair nasa. Fakultas Pertanian, Universitas 17 Agustus 1945. Samarinda Hal 11.

Nurhidayah. 2015. Respon pertumbuhan tanaman jagung manis (Zea Mayssaccharata Sturt) terhadap kombinasi pupuk Bio-slurry padat dan pupuk anorganik. Skrpsi. Fakultas Pertanian, Universitas Lampung, Bandar Lampung, 7-11 hal.

Purwono, M. Dan Hartono , R.2007. Bertanam Jagung Manis.Penebar Swadaya Bogor.68 hal.

Riwandi, Handajaningsih, M, Hasanudin, 2013. Rekayasa Kualitas Kesuburan Tanah Tanah dengan Pupuk Kompos dan Aplikasinya Terhadap Produksi Jagung Organik Laporan Hasil Penelitian Strategis Nasional Tahun ke 1, Fakultas Pertanian Universitas Bengkulu Desember 2013.

Rukmana, R. 2007. Jagung : Budidaya, Pacapanen, dan Penganekaragaman Pangan. CV. Aneka Ilmu. Semarang.

Sarief, E. S. 1998. Kesuburan dan Pemupukan Tanah Pertanian. Pustaka Buana. Bandung. 
Stepanus, B. 2014. Serapan Nitrogen Oleh $20 \quad$ Varietas Jagung Manis pada Sistem Pertanian Organik. Skripsi.Universitas Bengkulu : Bengkulu.

Sudarto, M Zairin, Awaludin Hipi, dan Ari Surahman, 2003. Pengaruh Jenis Pupuk dan Dosis Pupuk Kandang Terhadap Pertumbuhan dan Hasil Produksi Jagung Manis (Zea Mays saccharata Sturt). Pastura (1):2.

Supardi, Agus. 2011. Aplikasi Pupuk Cair Hasil Fermentasi Kotoran Padat Kambing Terhadap Pertumbuhan Tanaman Sawi (Brassica Juncea ) Sebagai Pengembangan Materi Mata Kuliah Fisiologi Tumbuhan. Skripsi

: Program Studi Pendidikan Biologi FKIP Universitas Muhammadiyah Surakarta.

Sutedjo, M.M, 2002. Pupuk dan Cara Pemupukan. Penerbit Rineka Cipta, Jakarta. Hal 42. Sudarto, M. Zairin, Awaludin Hipi dan Ari Surahman, 2003. Pengaruh Jenis dan Dosis Pupuk Kandang terhadap Pertumbuhan dan Produksi Jagung Manis (Zea mays saccharata Sturt). Pastura (1): 2.

Sutanto. 2002. Perbedaan Antara Pupuk

Anorganik dan Pupuk Organik.

http://

repository.ipb.ac.id/bitstream/handle/

12345689/52826/BAB\%20I\%20Pen

dahuluan.pdf ?sequence=3. [27 April

2012].

Suwahyono, U. 2011. Petunjuk Praktis

Penggunaan Pupuk Organik secara

Efekktif dan Efisien. Penebar

Swadaya : Jakarta.

Syahni, R. dan Nelly, N .2017 Analisis Statistik Untuk Penelitian Pertanian, Andalas Uversity Press. Padang. 321.

Syukur, M dan Rifianto, A. 2013. Jagung Manis. Jakarta(ID): Penebar Swadaya.

Syukur, M dan Rifianto, A. 2014. Jagung manis. Jakarta: Penebar Swadaya .

Trisnadewi. Susila dan Wijana. 2012. Pengaruh Jenis Dan Dosis Pupuk Kandang Terhadap Pertumbuhan Dan Produksi Jagung Manis (Zea Mays Saccharata Sturt. Program

Studi Peternakan, Fakultas Peternakan Universitas Udayana.

Tuherkih, E. Sipahutar, I.A. 2008. Pengaruh Pupuk NPK Majemuk (16:16:15) Terhadap Pertumbuhan dan Hasil Jagung (Zea Mays L) Di Tanah Inceptisols. Balai Penelitian. Tanah 77-88.

Yulisma.2011.Pertumbuhan dan Hasil beberapa Varietas Jagung pada Berbagai Jarak Tanam. Penelitian Pertanian Tanaman Pangan. 30

(3):196-203

ke-k 